s mounsies

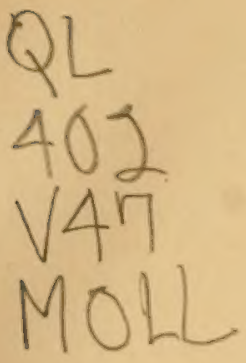

Verrill, Addison 8

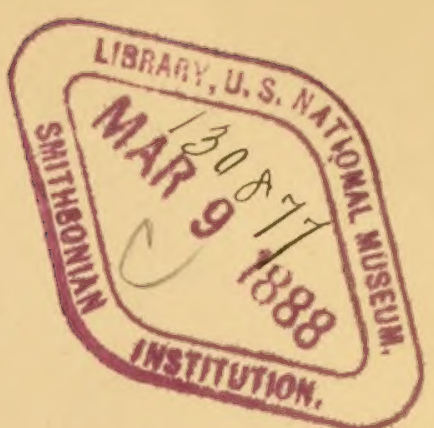

\section{Collected warks.}

mollusks.

(Binders title.)

Division of Mollusles Sectional tibrary

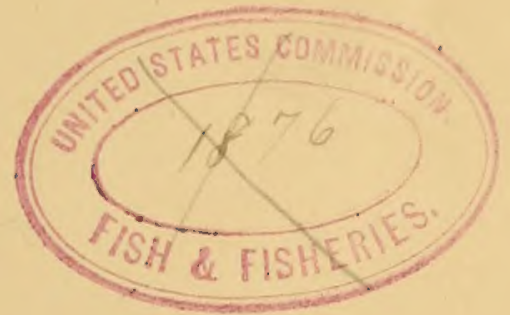





Remarks on certain Errors in Mr. Jeffreys's Article on "The Mollusca of Europe compared with those of Eastern North America ;" by A. E. VERRILL.*

IN the October number of the Annals and Magazine of Natural History, Mr. Jeffreys published an article upon this interesting subject, in which many important errors occur, due, no doubt, to the fact that the distinguished author is much less familiar with American than with European shells. But as the dredgings in connexion with the investigations of our fisheries by the U. S. Fish Commission were under my superintendence during the two past seasons, and Mr. Jeffreys alludes to the fact (though rather indefinitely) that he, by invitation of Professor Baird, accompanied us on several dredging-excursions in 1871 , it seems necessary that I should point out some of the more important of these errors, lest it be supposed by some that the same views are held by me.

It is not my intention to discuss at this time the numerical results presented by Mr. Jeffreys; but I would remind the readers of his article that the regions compared are in no respect similar or parallel, and that it is scarcely fair to compare the shells from the entire coast of Europe with those from about 200 miles of the coast of New England, where the marine climate is for the most part more arctic than that of the extreme north of Scotland-and, moreover, that the last edition of Gould's "Invertebrata of Massachusetts" contains only a part of the species added to our fauna since the first edition was published in 1841, and very little of the great mass of facts in regard to distribution, \&c., which have been accumulated by American naturalists during the last thirty years. Consequently that work is far from being a good "standard of comparison." To make a just comparison, all the shells on our coast, from Labrador to Florida, should be compared with those of Europe.

And without going into a long discussion of his peculiar views on the geographical distribution of our shells, I would

* From the Annals and Magazine of Nat. Hist., IV, vol. xi, p. 206. 
remark that, to an American, it seems rather singular that most European writers, whether zoölogists or botanists, find it necessary to trace back to a European origin all the existing species of this country, and to suppose that they have "migrated" from Europe to America and other countries in spite of opposing currents and all other obstacles. Thus Mr. Jeffreys can imagine that our land and freshwater shells could have migrated from Europe all the way across Asia, the Pacific Ocean and North America in order to reach Canada and New England; but he does not seem to think it possible that they may have originated in America, and thence crossed to Europe in the direction of the prevailing currents and winds. Nevertheless geology teaches us that America was a great continent, in very early ages, when Europe was only a group of islands; that no other country is richer in the remains of terrestrial animals and plants connecting the Tertiary and Cretaceous ages with the present; that many of these supposed European forms (whether terrestrial or marine) can be traced back into our Tertiary formations quite as far (if not farther) than they can in Europe; and that many of the genera of animals, and especially of plants, now found living in both countries, can be traced back to the Cretaceous in America and only to the Tertiary in Europe. Moreover the great number and diversity of the land and freshwater shells of America (e.g., of Unionida, Melanioe, \&c.), and the peculiar facts in their geographical distribution, cannot but convince any one familiar with the subject that they have originated in America at a very remote period; which is confirmed by the fact that many of these can be traced far back into our Tertiary formations. Nor are there sufficent reasons for supposing that those of our species living also in Europe have had a history different from those that are still peculiar to America.

Of course, no one will deny that certain species of land-shells have been introduced from Europe in modern times by human agency; but, so far as most of the identical species are concerned, it seems to us far more probable that America gave them to Europe, rather than the contrary, and this whether animals or plants, terrestrial or marine.

But the special errors to which I wish to call attention occur in the table of species, showing their geographical distribution. These relate both to the names and specific identity of certain shells, and to their geographical distribution. Although not agreeing with the author in regard to many of his remarks concerning the generic relations and names of species, I do not propose to discuss them here; for there seems to be no danger of their general adoption, either in Europe or America.

The following marine species (named as in Gould), which Mr. Jeffreys puts down as belonging to the region north of Cape 
Cod, actually belong properly to the region south of Cape Cod, extending in most cases to the Carolina coasts or beyond, while north of Cape Cod they are rare or local, viz.:-Cochlodesma Leanum, Mactra lateralis, Petricola pholadiformis, P. dactylus, Gouldia mactracea, Cytherea convexa, Venus mercenaria, V. notata, Gemma gemma, Liocardium Mortoni, Arca transversa, Modiola plicatula, Pecten irradians, Ostrea Virginiana, Anomia electrica (not of Linn.), Diaphana debilis, Cylichna oryza, Placobranchus catulus, Crepidula fornicata, C. plana, C. convexa, C. glauca, Tanthina fragilis, Bittium Greenii, Odostomia bisuturalis, O. seminuda, Turbonilla interrupta, Pleurotoma bicarinata, P. plicata, Nassa obsoleta, Buccinum cinereum, Diacria trispinosa, Loligo Pealii.

The following, to which a northern distribution is likewise given, are also found far south of Cape Cod, and many of them belong quite as much to the southern as to the northern division; and some of them are decidedly southern, extending even to the Gulf of Mexico:-Teredo navalis, T. megotara, T. chlorotica, Solen ensis, Machara costata, Pandora trilineata, Lyonsia hyalina, Mactra solidissima, Kellia planulata, Macoma fusca, Tellina tenera, Astarte castanea, A. quadrans, A. sulcata, Nucula proxima, Yoldia limatula, Mytilus edulis, Elysia chlorotica, Crucibulum striaturn, Littorina rudis, L. tenebrosa, L. palliata, Lunatia heros, L. triseriata, Nassa trivittata, Melampus bidentatus, Alexia myosotis.

Many others, not named in the above lists, are not limited by Cape Cod; but as they belong properly to the northern division, they are here omitted.

As an offset of these numerous instances in which he has unduly exaggerated our northern fauna, we find not one undoubted instance of an error on the other side, among the marine shells.

The distribution indicated for our land and freshwater shells is even more erroneous. It is sufficiently evident that Cape Cod is in no sense a proper boundary between the northern and southern fluviatile and terrestrial species; but, disregarding this, there are no reasons whatever for most of the special indications that he gives.

Thus he gives the northern distribution to all of the sixteen species of Sphcerium and Pisidium; but most of them are well known to be widely distributed over the eastern, middle, and western parts of the United States, some even extending to the southern parts. Unio complanatus, U. nasutus, Margaritana arcuata, and Anodon impticatus are indicated as distributed north of Cape Cod; but all these are found over most of the northern and middle states and some in the western, while the last one is somewhat rare at the north. But Unio radiatus, U. cariosus, U. ochraceus, Margaritana undulata, M. marginata, An- 
odon fluviatilis, and $A$. undulatus are put down as southern. It would certainly be difficult to show that these, as a group, are more southern than the previous lot; for most of them have nearly the same wide distribution, and all of them, except $U$. cariosus, occur even in Maine. Some of them (as U. radiatus, M. undulata, and $A$. fluviatilis) are the most abundant species in all the waters of northern New England and New Brunswick. The distribution given for the species of Valvata, Melantho, and Amnicola is equally faulty.

All of the eighty-one species of Helix, Hyalina, Macrocyclis, Limax, Pupa, Vertigo, Succinea, Arion, Zonites, Tebennophorus, Limnoea, Physa, Bulinus, Planorbis, and Ancylus are set down as having the northern distribution, except Hyalina Binneyana, Pupa fallax, Limncea catascopium, and Physa ancillaria. But every American conchologist knows that nearly all of those species are very widely distributed over North America, east, west, north, and south, many of them being limited only by the Gulf of Mexico on the south and California or the Pacific on the west. Nor is there any reason for the distinction made in the case of the four species named above; for these, though differing among themselves, have the same distribution as many of those put down as northern, while $H$. Binneyana and $P$. ancillaria certainly have a very northern range, for they are abundant in Maine, New Brunswick, and Canada.

It is evident that such numerous errors of this kind render the paper, so far as geographical distribution is concerned, quite worthless; for it is sure to mislead.

Most of these errors might have been easily avoided had the author depended less on Gould's work and more on the recent works of American conchologists; for there is no lack of data in regard to the distribution of most of our shells. Even Dr. Stimpson's "Shells of New England" (1851), if consulted, might have saved most of the errors in regard to the distribution of the marine shells.

The fact that there is in the southern and shallower parts of the Gulf of St. Lawrence an isolated colony of southern shells, may have misled Mr. Jeffreys in many cases, especially as he evidently consulted the Canadian collections much more than those of the United States, many of the largest of which he did not see at all. In respect of erroneous identifications and the reduction of certain species to varieties, there is also much to be said; but this article is already so long that it will be necessary to refer only to some of the more obvious and important errors of this kind, leaving the rest to be discussed more fully elsewhere.

Every naturalist should be willing to allow his fellow naturalists full liberty of opinion with respect to the specific identity 
or difference of closely allied forms; and no one can claim to be infallible in such matters. Some of the error's to be mentioned do not, however, come under this head; for the species united have only remote affinities. Nevertheless the naturalist who has collected and carefully studied animals in their native haunts, under various circumstances, in many localities, and in great numbers, has, other things being equal, a very great arlvantage in these matter's ; and therefore I believe that $\mathrm{Mr}$. Jeflreys would in most cases arree with me harl he collected and studied as many $\Lambda$ meriean shells as I have, during the past filteen year's, or if he were as familiar with them as he is with the British species. In most of the cases to which I refer, my own conclusions are in harmony with those of Dr. Stimuson, who devoted so many years to collecting and carefully studying on shells, and who is well known for his accuracy in such matters. And it would be strange indeed if all Ameriean naturalists as well as many eminent foreign ones, have always been making such ridiculous blunder's in regard to some of our most familiar shells as Mr. Jeffreys would have us believe.

Thus he states (p. 240) that "Gemma gemma" (or Totteniu gemma) is the young of Venus mercenaria! But it has long been known to European as well as American conchologist. that the animal of gemma is very different from that of mercenaria, and quite peculiar; that the hinge is constructerl on a very different type is well known; and Prof G. II. Perkins has shown (Proc. Bost. Soc. N. H., 1869, p. 148) that gemma is viviparous, producing about three dozen young, with well-formed shells, at one time. Moreover, the young shells of mercenariu, smaller than the adult gemma, are sufficiently abundant on our shores, and may be seen in many American collections; they are certainly very unlike the genma in form, sculpture, and hinge, as has been well known for more than thirty years.

Again, he states that Arca transversa is a variety of Arca perata, the former being put down as northem, the latter as southerm. That these shells are widely different in lorm and in the structure of the hinge is well known; for Dr. J. E. Gray many years ago established a new genus (Argina) for the latter, on account of its very peculiar hinge. That the animals are also quite different I can assert from personal observation. Moreover, the differences in the hinge, epidermis, and form are remarkibly constint; and, finally, the two speeies have the same geographical range from Cape Cod to Snuth Carolina, and are often found together. Both are very common in Long Island Sound and New IIaven harbor; and I have examined hundreds of speeimens of both species without finding the slightest evidence in fitvor of Mr. Jeftreys's views. Indect, they are only distantly related, and evidently belong to distinct gen- 
era, Argina and Scapharca, where several writers have placed them.

He also states that Mactra ovalis is a variety of $M$. solidissima. He may not have seen a specimen of the true ovalis, for it is not common in collections; but the genuine ovalis is certainly a very well-marked species, widely different from the solidissima. They differ greatly in the linge, epidermis, form of shell, and position of the umbos: moreover, the animals are also quite different. Both occur together of equal size in the Bay of Fundy; but the former is not known south of Cape Cod, while the solidissima is abundant everywhere along our sandy shores to South Carolina.

Concerning Astarte castanea he says, "Perhaps a variety of A. borealis Ch. ;" but castanea is one of the best-defined species in this difficult genus, varies comparatively little, and does not extend far north, its range being decidedly southern. It is perfectly distinct from $A$. borealis. He reduces $A$. quadrans to a variety of $A$. castanea, and gives it a name that is quite uncalled for, even if this view were correct. He then makes $A$. Portlandica a variety of $A$. compressa; but I have already shown (Amer. Journ. of Science, A pril, 1872) that it is a variety of $A$. qualrans. His arrangement of the other species of Astarte is equally objectionable, but it is not necessary to discuss them here.

The Pecten fuscus Linsley is given as the young of P. irradians, from which it is very distinct; but the writer has shown (Amer. Journ. of Science, vol. ii, p. 361, and vol. iii, p. 213, 1871-72) that it is really the young of $P$. tenuicostatus.

Dekay is given as the authority for Eolis salmonacea and $X$. Iymnota; but they were both described by Couthouy in 1838, from whom Dekay borrowed both the descriptions and figures, five years later.

Mle states that Dentalium dentale (non Linn.) is a variety of Entalis striolate, and that the latter is a variety of $D$. abyssorum Sars; but both of these statements are incorrect. The first is the Dentalium occidentate Stimpson, and is a true Dentalium, entirely different, generically and specifically, from the striolate; and the latter is also quite distinct from abyssorum. Possibly Mr. Jeffreys has not seen perfect specimens of all the American species; otherwise, I cannot understand how he could have made these statements.

IIe is correct in considering Crepidulu glauca a variety of $C$. fornicatn, as others have done before him; but he has adopted a serious mistake, made by several other writers, in regarding C. plana (or unguiformis) also as a variety of C. fornicata, from which it is really very distinet. It is a very common error to suppose that this species always inhabits the inside of dead uni- 
valve shells; for it very often occurs on the outside of such shells, on stones, the back of Limulus, \&c., and is frequently associated intimately with fornicat in all these situations; but nevertheless it always retains its essential characters, under all circumstances. The typical fornicata is also often found with it, plentifully, on the inside of dead shells.

Nor can MIargarita acuminata be the young of M. varicosa; for in our collection there are full-grown specimens of both, equal in size, from Labrador.

There is no sufficient reason for adopting the name Lacunc divaricate in place of $L$. vincta; for it is not the Trochus divar $i$ catus of Limne (1767), although it is the shell described under the same name by Fabricius in 1780, as shown long ago by Dr. Stimpson and others. Fabricius made a mistake which we have no right to perpetuate; nor does "usage," to which Mr. Jeffreys so often appeals, sanction the change.

The Lumatia triseriata is not, as $\mathrm{Mr}$. Jeffreys thinks, the young of $L$. heros, but only a color-variety, as the writer had previously shown (April, 1872). Both varieties occur together, from the smallest to the largest sizes; but the former sometimes becomes plain colored before reaching maturity. There is no evidence that Natica clausa is the Nerita affinis of Gmelin, but quite the contrary; for the latter was placed in the section of umbilicated species, was described as silvery within, and came from New Zealand! It is probably one of the Trochida, and certainly could not have been this imperforate Natica.

In this place I shall not enter into a discussion of the numerous cases in which the author has reduced the American shells to "varieties" of the European species, because in many of these cases there must long be great diversity of opinion, and for most purposes it matters little whether these closely related forms be called "varieties" or "species," so long as the actual differences are recognized. But since Mr. Jeffreys has evidently made so many important mistakes in his article in regard to the identity of species, and has united those that have no near affinities, as already shown, it is logical to conclude that he may have made other mistakes in the case of more critical species. He must therefore pardon us if we regard his recisions in all these cases as at least doubtful, until confirmed by other evidence. 




DD 32

32

5)

(2)

3 i)

3D

3

SD.

5

35

3

32

32

32

2

$i_{i \infty} 35$

325

353

3013

S3) 33

3) 32

3.) 32

- 20,2

323

23. 23

3

3. 3

is

$3.3: 23$

(5)

33,3

2) 3

त) 33

$32) \geqslant$

(i) 2353 ?

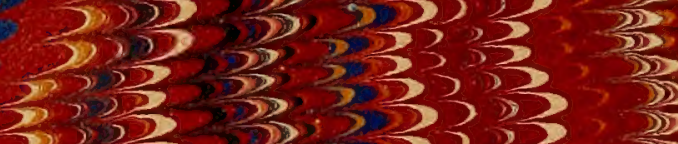

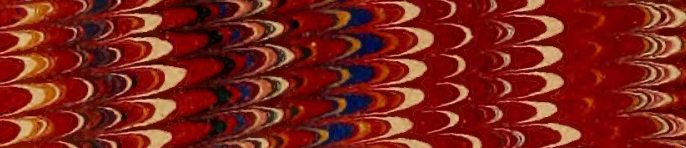

3) 323,33

य, 3,3$\} ?$

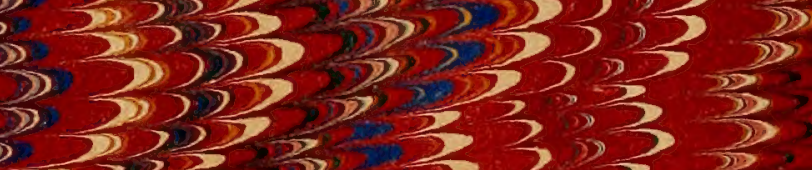

$3,353,53$

$33323,3>3, \frac{3}{3}$

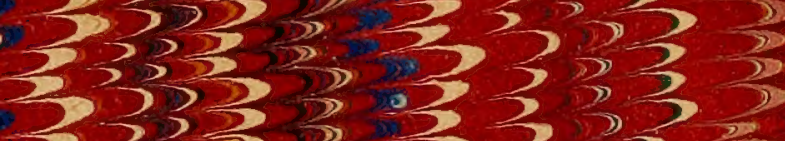

$333 \frac{3}{3} 3,3,3,23$

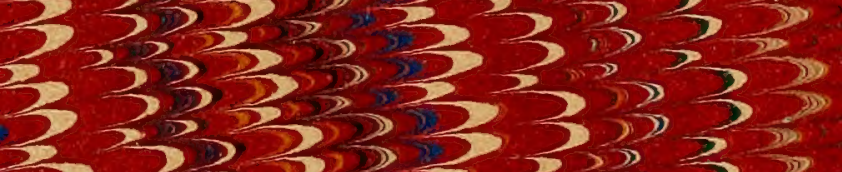

33333

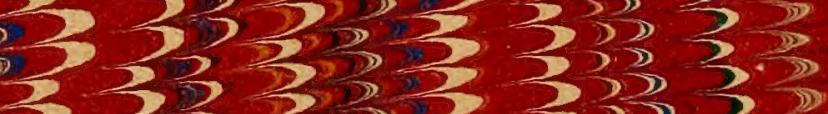

$33 \frac{3}{3}, 33 \pi 3$

$3 \frac{3}{3}$

30

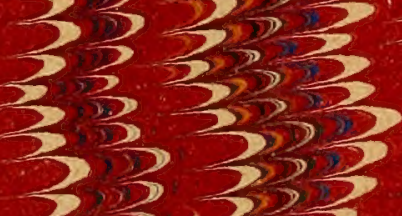

$3,3>33$

$3,3=35$

$3 \sum_{3 \infty}$

$3 \rightarrow \infty$ i) $32 \sum_{3}^{3}$

325

323 $32 \frac{5}{2}$

33

$3>$ $3 \gg ?$

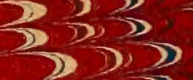

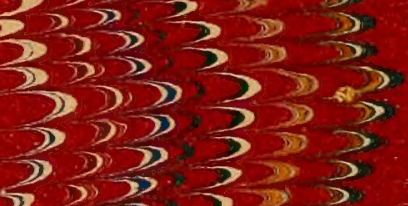

$\sum_{3}^{3}$.

$\sum_{3} \sum_{3}^{\infty} \sum_{3}^{\infty}$

333

35

3

3

3

3

3

3

3

3

3

3

sis

3

$\rightarrow 33$

D

D. 232

3

(-3)

Din 333

$\sum_{3}, 3,3$

$m_{3}, 333$

) 3

$3>3$

m. 335

3.

$\pi>$

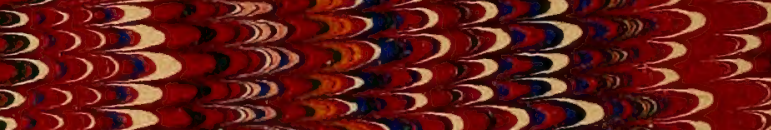

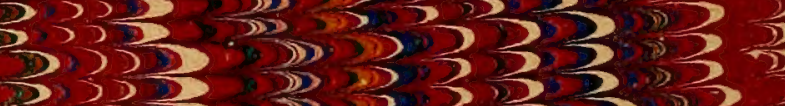

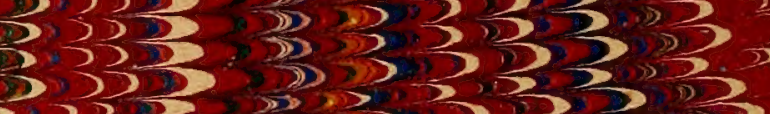

$\sum_{3}^{3} 35$

$3_{3} \int_{3} 3_{3}$

$\sum_{\infty} \sum_{3}^{3} \sum_{3}^{3}, 3$

i) 333

335

323

$3>3$

$3 \sum_{3} 3, \frac{3}{3}, \frac{3}{3}, \frac{3}{3}, \frac{3}{3}$ $3,3,3,3, \frac{3}{3}, 3,3$

3

$\rightarrow 33_{3} 3$

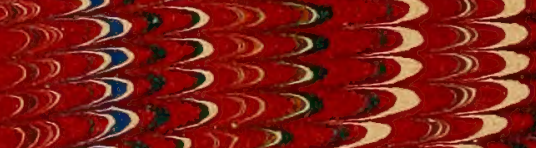

3003

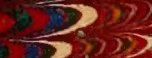

,

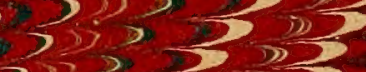

(2) $\rightarrow, 25$

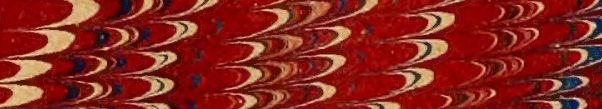

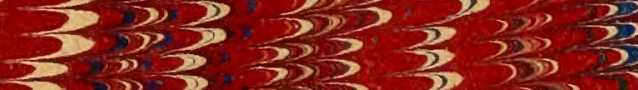

$3,3,325$

$3.25>35$

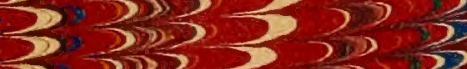

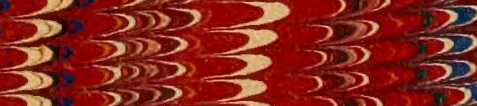

3253

(2) $25 \times 3$

$\sum_{3}$

沙, $\sum_{3}, \frac{25}{3}=\frac{3}{3}$ 3

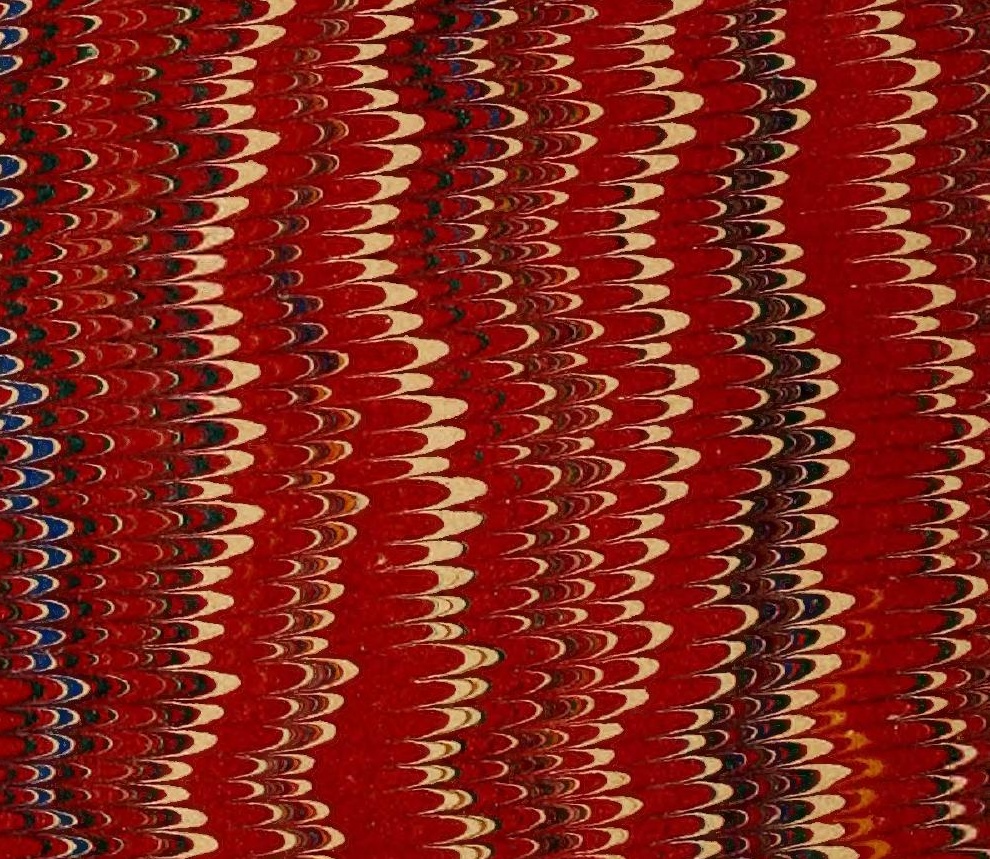

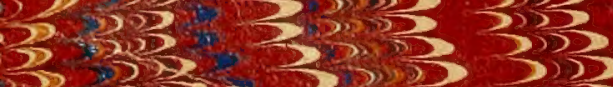


se

253 
